\title{
Collaborating for resilience: conflict, collective action, and transformation on Cambodia's Tonle Sap Lake
}

\author{
$\underline{B l a k e ~ D . ~ R a t n e r ~}^{1}, \underline{\text { Kosal Mam }}^{1}$ and Guy Halpern ${ }^{1}$
}

\begin{abstract}
We report on outcomes and lessons learned from a 15-month initiative in Cambodia's Tonle Sap Lake. Employing the appreciation-influence-control (AIC) model of participatory stakeholder engagement, the initiative built shared understanding of the sources of vulnerability in fisheries livelihoods and catalyzed collective action to support resilience in this valuable and productive social-ecological system. Outcomes include the transfer of a large, commercial fishing concession to community access, and resolution of a boundary dispute involving community fishery organizations in neighboring provinces. Motivated by these successes, the main national grassroots network representing fishing communities also modified its internal governance and strategy of engagement to emphasize constructive links with government and the formal NGO sector. The AIC approach, we argue, provides an effective route to enable collective action in ways that strengthen dialogue and collaboration across scales, fostering the conditions for local-level transformations that can contribute to improvement in governance. We conclude with a discussion of the broader implications for resilience practice.
\end{abstract}

Key Words: Cambodia; civil society; collective action; community-based management; fisheries; governance; resilience; resource conflict; Southeast Asia; stakeholder collaboration; transformation

\section{INTRODUCTION}

At the heart of resilience thinking lies analysis of dynamic processes of change, that is, how social-ecological systems can retain key functions amidst stresses and shocks, how they adapt, and how they can be transformed (Folke et al. 2010). Although much of the early research on resilience focused on operationalizing the concept and developing a framework and tools for assessment (Walker et al. 2009), one of the vital frontiers today is practice, or how to actively promote resilience, adaptation, and positive transformation (Walker and Salt 2012).

This article, focused on a collaborative initiative addressing resilience of community fisheries in Cambodia's Tonle Sap Lake, is an example of "reflective practice" (Gunderson et al. 2007). Specifically, it examines an effort at "deliberate transformational change" (Folke et al. 2010), facilitated by "actors and organizations that bridge the local to higher social-ecological scales" (Olsson et al. 2004). Contributing to such transformation is challenging even when there are governance institutions in place meant to ensure a voice for all resource users and an opportunity to participate in, or influence, decision making (e.g., Gooch and Warburton 2009, Walker et al. 2009). Especially challenging are situations in which poor local resource users are marginalized in social, political, and economic terms, and where there is active conflict over resource access and use, or a high risk of such conflict.

In such circumstances, practitioners of development and environmental management need effective models of organizing amidst power imbalances and conflict to address challenges of governance. Such multistakeholder processes need to extend beyond discrete management decisions to build learning about longer term processes of change (Jacobs et al. 2010). One such model is Appreciation-Influence-Control (AIC), a framework for understanding stakeholder interactions and organizing for social and institutional change, distinguished by its emphasis on whole systems, open search for solutions, and explicit treatment of power.

We examine outcomes and lessons learned from a 15-month initiative employing the AIC model of participatory stakeholder engagement. The initiative aimed to build collective understanding of the sources of vulnerability in fisheries livelihoods and to catalyze efforts to support resilience in the valuable and productive Tonle Sap Lake fishery. A secondary aim was to document and reflect on the change process underway and its outcomes, and the lessons this yields regarding the AIC approach. The combination of these goals, i.e., joint assessment, action, and learning, exemplify the broader set of participatory learning and action (PLA) and participatory action research (PAR) principles (Chambers et al 2006, McIntyre 2008). The AIC model was chosen because, although there is very little documented evaluation of its application in natural resource sectors, its orientation toward whole systems, stakeholder-driven decision making, and explicit treatment of power appeared well matched to the problem of catalyzing collective action to address shared challenges of natural resources management.

The case demonstrates the potential of such an open-ended process of action research to enable collective action and improve natural resource governance, even amidst ongoing resource conflict. Outcomes include shifts in fishery access rights and resource management authority, notably the release of a large, commercial fishing concession to access by local communities, and the resolution of a boundary dispute involving community fishery organizations in neighboring provinces. Motivated by such successes in collaborative problem-analysis and advocacy, the main national grassroots network representing fishing communities also modified its internal governance and strategy of engagement to emphasize constructive links with government and NGOs working across a range of rural development sectors. 
We summarize the AIC model and its background, provide an overview of its application in the Tonle Sap fisheries case, and present key outcomes, followed by a discussion of lessons learned to inform future efforts that apply AIC or similar approaches to multistakeholder engagement under conditions of resource competition. The AIC approach, we argue, provides an effective route to enable collective action in ways that strengthen dialogue and collaborative interactions across scales, fostering the conditions for local-level transformations that can contribute to broader governance reforms. We conclude with a discussion of the broader implications for resilience practice, signaling the need for systematic comparison of similar action research experiences across multiple types of resource systems and in varied sociopolitical contexts.

\section{THE APPROACH: APPRECIATION-INFLUENCE- CONTROL}

AIC is a whole-systems approach to stakeholder interaction, analysis, and collaborative planning. Applicable in small as well as very large groups, the approach entails developing a shared appreciation of the context for the issue at hand, sharing experience with the aim of influencing others perspectives and preferences for potential courses of action, and finally narrowing in on the particular realm of actions within an individual's or group's control. By distinguishing factors that can be appreciated, influenced, and controlled, the model makes explicit recognition of the whole context for action and the power of different actors who are either directly engaged or who have influence on the outcomes (Smith 2008). Conceptually, this dynamic interaction is represented in three dimensions as nested levels of power, organization, and purpose (see Fig. 1). Critically, power is conceived not as a zero-sum game (one's gain is another's loss) but as a realm that can be expanded as different actors identify together with higher levels of common purpose, and then organize to achieve goals aligned with that purpose.

The foundation for AIC as an organizing process in international development emerged as a critique of the failures of the

Fig. 1. The Appreciation-Influence-Control model: an overview. Source: Smith (2008), reproduced with permission.

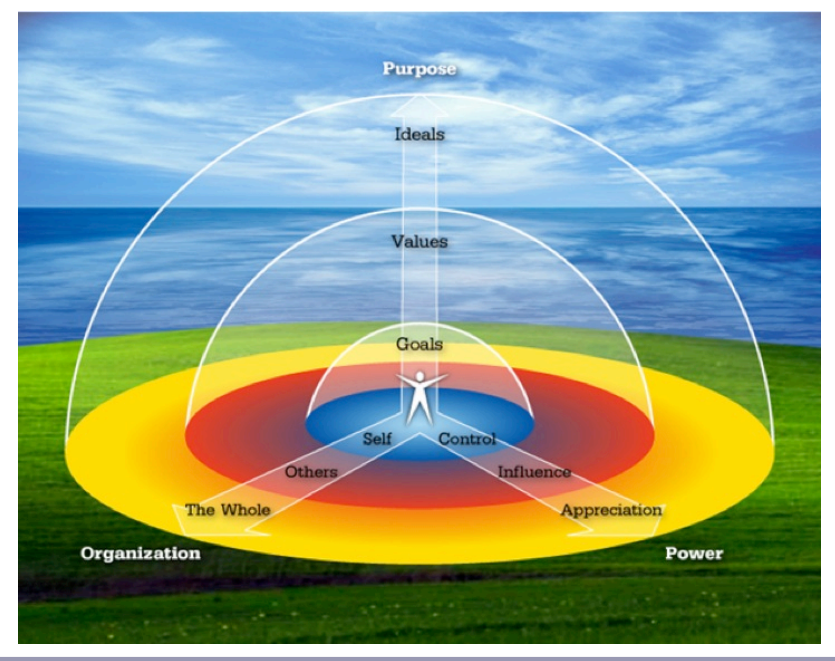

conventional project approach of the World Bank, where a control-centered model derived from engineering had been carried over into the field of rural development, effectively ignoring the dispersed and contested dynamics of power (Smith et al. 1980). A crisis in the energy sector in Colombia in 1985 provided the opportunity for the first large-scale application of the AIC organizing process, and helped legitimize the notion of stakeholder engagement to produce solutions that are contextualized within the broader constraints and opportunities afforded by cultural, societal, and political factors (World Bank 1996). The approach was later applied to community-driven development planning in rural Thai villages, focused on women's empowerment, natural resource management, and reproductive health (MacNeil 1998), and was replicated in diverse realms of Thai development planning from local to national levels addressing rural and urban poverty (Furugganan and Lopez 2002).

The AIC organizing process is not a methodology in the strict sense but rather a framework for investigation and action when diverse actors and interests are involved (MacNeil 1998). Although the details of the process are meant to be adapted to the particular context in which it is applied, generally it is a facilitated process bringing together participants representing (as much as feasible) the whole range of stakeholders, and calls for a purposeful focus on the three phases in sequence:

1. Appreciation: What is the purpose that different actors are striving toward? What are the elements of shared purpose? What is the current reality? What are the factors that constrain or enable progress toward that desired future? The appreciation phase is focused on increasing awareness of the whole system, and the perspectives of all actors involved. There is no judgment, critique, or debate; participants are asked to share their insights without regard to status or position.

2. Influence: What are the potential courses of action? What are the merits and risks of alternative paths? What roles could each actor potentially play in either advancing or blocking progress? The influence phase is characterized by intense debate, and convergence and divergence in values are made explicit and explored; participants negotiate and aim to influence one another.

3. Control: What specific actions am I (or my group) ready to commit to in service of a shared purpose? How will we gather the resources required, monitor progress, and increase our capacity to achieve these goals? Who else do we need to engage? The control phase focuses on developing a plan of action, making explicit commitments, and taking first steps; participants choose their commitments without coercion, motivated by their appreciation of broader needs and possibilities.

These phases of the AIC process can be applied and repeated in a wide range of contexts, from a single meeting, to a full day or multiday workshop, to a longer term initiative. The basic principles can be made more or less explicit as the situation demands. As was demonstrated earlier in Thailand, this is a flexible process; local organizers have been able to adapt to new sectors and to help coordinate and bridge actions from village to 
national scales (Furugganan and Lopez 2002, Layanun 2004). For the Tonle Sap initiative described in this paper, the originator of the AIC approach worked with the action research team to assist in adapting the principles as specific guidance for practitioners in the context of rural livelihoods dependent on contested natural resources. Subsequently, this was expanded with insights from the experience in Cambodia, as well as from parallel applications in Zambia and Uganda. The resulting practitioner guidance note on "collaborating for resilience" (Ratner and Smith 2014) provides advice on applying the three phases of AIC in scoping the potential for collaboration, convening and facilitating dialogue among diverse stakeholders, and in supporting action innovations and learning over time.

As an organizing framework, AIC can incorporate a wide range of participatory methods and tools. Visualization exercises such as problem tree analysis, identification of obstacles to change, collective timelines, and representation of alternative futures are widely used in such approaches as Participatory Rural Appraisal (PRA; Narayanasamy 2009) and Visualization in Participatory Processes (VIPP; Salas et al. 2006). Participatory tools for social network analysis such as NetMap (Schiffer and Hauck 2010) help identify and visualize stakeholder relationships. Each is useful to develop a shared appreciation of the context for action and a basis for dialogue, and can also be applied later in outcome evaluation. Methods developed for conflict resolution and negotiation, explicitly recognizing diverse stakeholder interests and underlying values, can be appropriate in the dialogue, or "influence" stage (Rüttinger et al. 2014). The tools of objectives-oriented planning, widely known by the German acronym ZOPP, with their explicit attention to articulating responsibilities, intended outcomes, and assumptions, can be adapted for the action planning stage, and subsequently for monitoring and evaluation. Elements of each of these were used in the case presented here.

One of the defining characteristics of AIC, however, is that, by aiming to balance these three different modes of interaction, i.e., appreciation, influence, and control, or "listening, dialogue, and choice" as described in the practitioner guidance note, it can help guard against the narrow application of any such methods or tools. PRA tools, for example, often are used simply as a means of information gathering or community-level consultation, leaving the real decision making and action planning to an expert or specialist group. Social network analysis can similarly be applied as an analytical tool without being embedded in a process of joint stakeholder reflection on pathways to influence. ZOPP methods can constrain an open dialogue over options for the future and the implications of different approaches if they too quickly channel participants to make a plan.

Another defining characteristic is the particular perspective on power, which informs and orients the whole AIC process. Many conceive power as the ability to impose one's will on others, what Weber (1947:152) articulated as "the probability that one actor within a social relationship will be in a position to carry out his own will despite resistance." As Gaventa (2006:24) explains, however, this notion of "power over" is just one conception. Also important is "power with," the possibility of achieving shared aims through collective action, and "power to," which Gaventa describes as "the capacity to act, to exercise agency and to realize the potential of rights, citizenship, or voice." An additional contribution of the AIC model, as Smith (2008) outlines, is to further distinguish among three dimensions of this "power to" achieve purpose: appreciation, influence, and control. This gives equal value and weight to appreciation in particular as a distinct source of power, one which is not directly defined or limited by an individual's social position or formal authority.

The three phases of the AIC process can be understood as efforts to exercise these three distinct powers: the power of appreciation, building a shared awareness of the broader context, the opportunities, and constraints; the power of influence, engaging in effective dialogue among diverse interest groups; and the power of effective decision making or "control," making responsible commitments and following through on these. One goal of the process is to have participants exercise these three powers in roughly equal parts, so that actions agreed reflect a careful consideration of the implications for other groups and other system levels.

As illustrated in the AIC model (Fig. 1), these three dimensions of power correspond as well to three levels of organization, in so far as every individual, group, or action can be conceived in terms of the domain of control (the self), the domain of influence (relationships with others), and the domain of appreciation (the whole system). Critical here is the ability to shift attention and effort from the individual or small group, to the realm of multistakeholder interaction, to the "whole system" of social and ecological relationships that affect the goals of an initiative. As explained through the example of the Tonle Sap experience, these domains are not fixed; the process of interaction can shift the composition of groups that form to work together, the extent and nature of their influence, and indeed their conception and understanding of the system in which they work. Essential to such shifts is the explicit discussion of purpose (the third axis in Fig. 1) also at multiple levels, from the most broadly shared ideals or aspirations, to divergent values, to the particular goals or objectives of the individual or group.

\section{ACTION RESEARCH PROCESS}

More than half of Cambodia's rural population depends on fish and aquatic resources for some portion of their livelihood. Fish is also the leading source of animal protein in the rural diet, and a vital source of nutrition in a country where $30 \%$ of children are undernourished. The Tonle Sap Lake, the largest lake in Southeast Asia, is the heart of this remarkably productive fishery. Today the resource is under threat from a combination of sources, including destructive fishing practices, land-use change, fishing beyond the natural capacity of the ecosystem to regenerate, and dam development in the Mekong upstream. As the range of competing uses of water and wetlands expands, and as competition over the fishery increases, the most vulnerable households risk being excluded (Keskinen et al. 2007, So et al. 2014).

Addressing the governance challenge of Tonle Sap Lake fisheries and livelihoods demands attention to the whole catchment, considering the influence of developments in upstream land use and water management, the social and ecological costs and benefits of shifting land use and fishing practices, feedback across scales, and the evolution of institutional arrangements in relation to governance needs (Walker and Salt 2012). The government's establishment of the Tonle Sap Basin Authority in 2007 represents the latest in a series of efforts to achieve stronger coordination 
among the multiple agencies and actors involved in resource management, conservation, and planning within the lake basin, though this has also brought additional tensions among the various agencies competing for authority, for example between the Fisheries Administration and the Ministry of Water Resources in the fisheries arena (Keskinen and Varis 2012). Within this institutional context, civil society organizations play a particularly crucial role as a conduit and bridge representing the interests of local resource users.

The evolution of rural civil society organizations and networks in Cambodia is shaped by and responds to this context of competition over environmental resources, particularly land, forests, and fisheries, given their central importance to rural livelihoods. The legal recognition of and political space for the growth of domestic nongovernmental organizations expanded significantly during the period of the UN peace mission in the early 1990 s and the establishment of the first coalition government following the elections of 1993. Many of the early domestic NGOs and less formal civil society organizations focused on reconciliation, service provision, and local community development, whereas significant numbers have since developed a more explicit focus on human rights and democratic governance, addressing issues such as illegal land acquisition and forest encroachment (Bandyopadhyay and Khus 2013). The prospect of new legal restraints on the civil society sector, along with significant inflows of foreign investment in resource sectors including mineral exploration and agroindustry, have increased the demands on civil society leadership, and the importance of broad partnerships and coalitions (PRIA 2012, Ratner 2013).

As players in this contested terrain, domestic civil society organizations face challenges that include costs of organizing, capacity to document and articulate their concerns effectively, and access to official decision making. A range of Western development agencies have sought to address these deficiencies, aiming to support the government's policy shift toward decentralized governance. In the fisheries sector, most attention has focused on establishing community fishery organizations and building their organizational capacity. A number of groups, including Oxfam and the East-West Management Institute, have worked in addition to strengthen grassroots civil society networks and build their capacity to advocate on behalf of marginalized communities. Forum Syd, a Swedish social justice collective, has played a particularly important role over the last decade by supporting the Fisheries Action Coalition Team (FACT) to nurture the growth of community-based organizations representing fishing communities, notably the Village Support Group and the Coalition of Cambodian Fishers (CCF), aiming to support their independence of analysis and action (M. Nee 2008, unpublished manuscript). FACT played a prominent role in bringing media attention to the concerns of fishing communities prior to the first wave of fisheries reform in 2000-2001. By 2008-2009, CCF had also become a vocal critic of the Fisheries Administration and local agencies, frequently cited in newspapers and appearing on the radio decrying alleged abuses by fishing lot operators and the persistence of official corruption as a cause of poor enforcement.

It was in this context of tension and considerable mistrust, in September 2009, that WorldFish and local partners launched an action research project with a purpose to strengthen the capacity of fishing communities of the Tonle Sap Lake to engage in collective action beyond the local scale, in support of governance arrangements that anticipate and manage competing uses of aquatic resources equitably. Specifically, it focused on the collective capacity of an emerging grassroots network of fishing communities to identify and articulate threats, negotiate with authorities to represent the common interests of fishing communities, and collaborate with government and private actors to resolve resource conflicts.

The initiative was distinguished from the outset by its commitment to shared ownership and decision making among a unique collection of partners. The three domestic partners were the CCF, the Fisheries Administration (FiA), and the Cambodia Development Resource Institute (CDRI). This brought together the most active grassroots network of fishing communities around the lake, the key sectoral authority within government, and the leading domestic policy research institute, with the rationale that jointly these groups would be able to draw in most other key stakeholders, as well as build a bridge between local and policylevel perspectives. WorldFish convened the parties to initiate the collaboration, and supported the domestic partners to undertake the dialogue process.

These four partners employed the AIC approach to plan the overall research and stakeholder engagement process, to structure and facilitate the dialogues, and to analyze emerging results collaboratively. A core team, composed of three to six representatives from each partner, organized a series of local and provincial dialogues in the five provinces that border the Tonle Sap Lake. These dialogues first engaged local stakeholders in assessing the character and roots of resource conflicts in the lake. The salient themes that emerged were destructive and illegal fishing practices, clearing of flooded forests, competing land and water use, and overlapping resource claims and boundary disputes, including significant ongoing tensions between community fisheries and the operators of commercial fishing concessions.

The dialogues also identified governance constraints that have obstructed efforts by different actors to address these problems, including poor coordination among government agencies across sectors and across levels of administration, weak accountability of authorities toward local constituencies, and ineffective mechanisms of recourse through the courts or administrative channels, and strategies to overcome these constraints. These results are presented separately in So et al. (2014). Although none of these governance constraints is wholly new, the legitimacy of the process came from the way these were identified collectively, rather than introduced by one group or by a set of external experts.

The overall development aim for the initiative was conceived as social-ecological resilience, encompassing improved livelihood security, reduced vulnerability, and sustained productivity of the fishery resource. In Khmer language, resilience can be translated as pheap thon, meaning ability to withstand and persist in the face of pressure, as bamboo in the wind; however the term is not widely used or understood in rural communities in relation to ecosystems or development. The notion of "sustainability," or nirontarakpheap, is now more familiar, in reference to livelihoods 
as well as resource systems. In the AIC framework, this articulation corresponds to the "ideal," which is noncontroversial and thus broadly shared.

Local discussions focused on the sustainability and security of livelihoods through strategies including income diversification and improving local capture of benefits along the value chain, as well as the ability to adapt and support one's family in the face of trends such as price shocks or declining catches. These more specific interpretations correspond to "values," reflecting different group perspectives. The most immediate level of purpose, labeled in Figure 1 as "goals" refers to action priorities by particular groups, such as the goal of expanding community fishing grounds. Framing "the system" at the scale of the Tonle Sap Lake rather than the more local scale of the community fishery or administrative unit encouraged local actors to consider a broader set of institutional relationships as well as ecological interdependencies. Although the whole lake is readily recognized as a shared ecosystem in everyday language, and as a focus of management in the context of the Tonle Sap Biosphere Reserve or the more recent Tonle Sap Basin Authority, it is less common for local stakeholders to engage in dialogue about livelihoods with that broader system as the frame. In this sense, exercising the appreciative power (awareness of the whole system) helps orient subsequent dialogue over divergent values and planning for specific goals to put resilience in practice.

Employing an action research approach (Whyte 1984), the partners agreed over a series of planning sessions that the goal was not only to study a problem, but also to work with local stakeholders in assessing both the underlying causes of the problem and possibilities for collaborative action to address it. Indeed, the core purpose was defined in terms of capacity for social and institutional change, with the functions of research, learning, and communication of outcomes conceived as supporting that core purpose. As the initial conveners of the collaboration, WorldFish researchers played an important role in defining these parameters, while subsequent decisions about framing and goals for the initiative were made jointly by the core team of partners once formed.

Site selection by the core team followed a purposive approach (Patton 1990), based on these criteria: (1) geographic diversity, with sites located in the five provinces surrounding the lake, enabling exchange of experiences and networking among participants in the research process across provinces; (2) issue diversity, with representation of a variety of conflicts with regard to scale of conflict, stakeholders involved, and resources in dispute (fishing access, water use, land tenure) that impinge on fisheries livelihoods; (3) established relationships by one or more of the partner organizations, providing a basis of trust that enables participants to quickly probe sensitive issues, and extend the analysis from local to broader scales; and (4) prominence of disputes, on the rationale that progress in addressing more difficult or enduring issues would assist in sharing the experience and scaling up. An overview map of the five local sites and key issues for each is provided in Figure 2.

The action research process began with a series of local and provincial dialogues convened in each of five case study communities. In each case, preliminary consultations in the communities provided an opportunity for community fishery members to identify the most relevant stakeholders affecting resilience of local livelihoods. The invitation to participate then came from these local groups, with invitations to government officials coming from the Fisheries Administration. The dialogues involved local fishers, fish traders, community fishery members and leaders from the host village and neighboring communities, police officers, commune council councillors or chiefs, and fisheries officers, as well as in some cases environment officers, military police, and district officials, a total of 172 participants in five local dialogues.

Each local dialogue was followed immediately, typically the next day, by a provincial meeting, which provided an opportunity for select participants from the local dialogue (chosen by participants as representatives) to present outcomes and explore further solutions with the next level of stakeholders, involving a broader range of provincial agencies, NGOs, provincial police, gendarme commissioners, sector department heads, and other senior government staff, a total of 113 participants in five provincial dialogues. Although it was not always possible to secure participation from every group invited, there were no groups specifically excluded. Larger commercial players, particularly the lot concessionaires, were difficult to engage, though in the case of the Kompong Thom provincial dialogue, a representative from fishing lot number 1 joined.

A national dialogue held at the Fisheries Administration headquarters in Phnom Penh in April 2010 was chaired by the Director General of the FiA and organized by CDRI, and included senior management from the FiA and other associated government agencies, the Tonle Sap Basin Authority, the Cambodian National Mekong Committee, and NGO representatives. Although many prior meetings had been organized by civil society groups such as FACT with an objective of raising public awareness of fishers' concerns, or by the government with an objective of providing training or sharing information or research results, this proved an unusual event in that it sought to continue the dialogue over solutions initiated at more local levels, with participants from CCF and the provincial dialogues buttressed by their ability to convey the conclusions of prior dialogues.

An outcome evaluation exercise, conducted in OctoberNovember 2010, at the end of the 15-month project period, entailed revisiting the case study sites and conducting follow-up interviews on events that had occurred in the intervening 8 to 12 months, depending on the site. Participants at all levels had undertaken a range of follow-on actions in response to the issues identified at the dialogues, sometimes with the support of the FiA and/or CCF, but without any direct assistance by the research partners (CDRI and WorldFish). Apart from minor costs to compensate for the time and travel of CCF partners, as well as travel and workshop costs for one follow up meeting convened by FiA, no additional project funds were applied in support of the follow-on actions.

\section{OUTCOMES}

Tracing patterns of causation between interventions and outcomes within complex natural resources management systems involving multiple stakeholders across different levels is an inherently difficult undertaking (Mayne and Stern 2013). Taking into account the importance of these multiple perspectives and 
Fig. 2. Tonle Sap Lake, showing local case study sites and key issues.

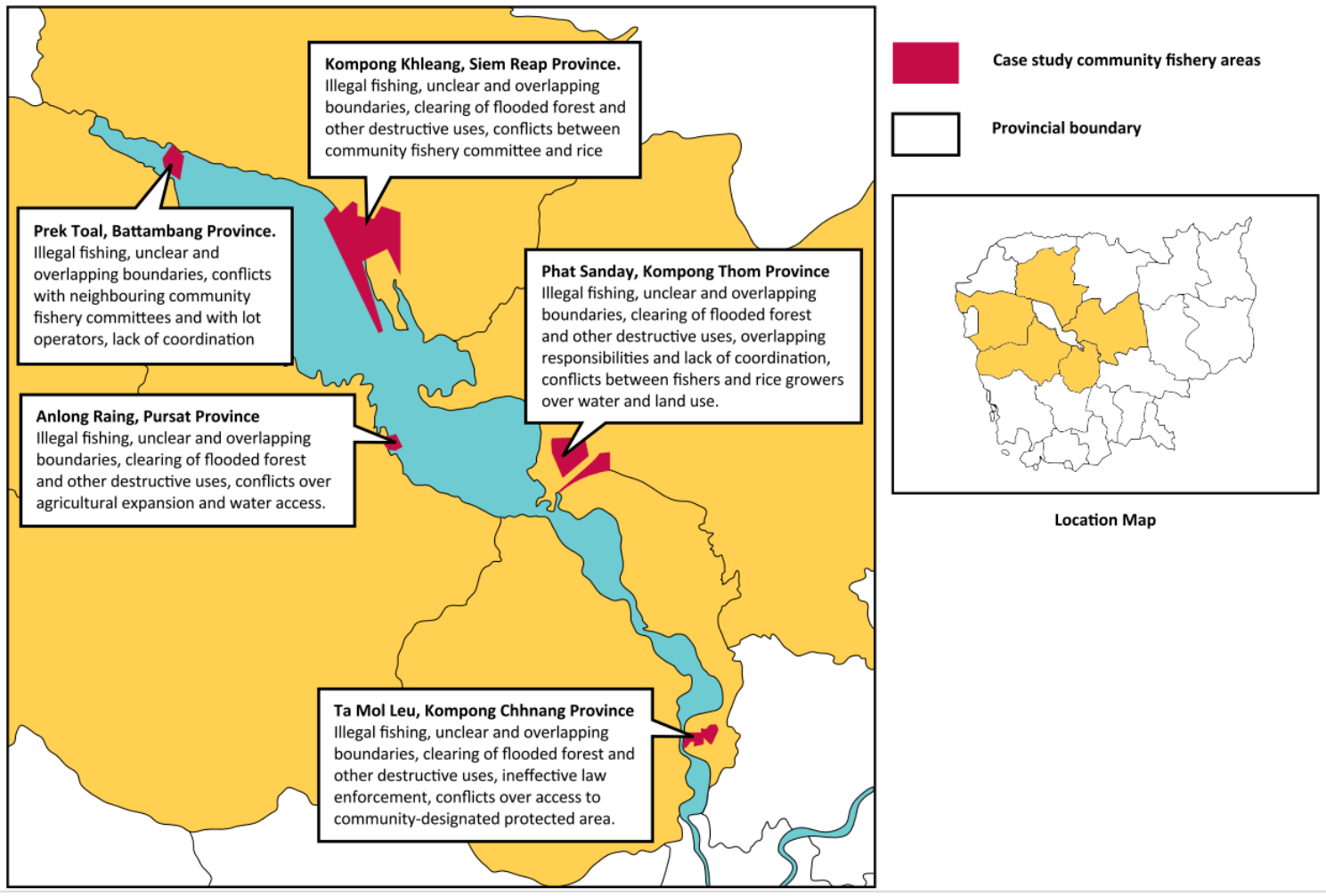

narratives (Leach et al. 2010), the initiative adopted a participatory approach to monitoring change and evaluating outcomes, centered around the most significant change methodology (Dart and Davies 2003).

The evaluation used semistructured interviews to elicit people's perspectives on the changes occurring in their lives and in their local context without prejudicing the answer in any one direction. To ensure a degree of neutrality in assessing outcomes, the interview team comprised a different set of researchers than those who took part in implementing the initiative, apart from one, who provided a necessary bridge of introductions and continuity for local stakeholders. The interviews were conducted with a wide variety of stakeholders, some who participated in the original consultations and some who did not. They included fishers, traders, police officers, village leaders, commune council members and leaders, community fishery members and leaders, and NGO representatives. Some of the interviews were conducted in small groups, while others were conducted individually; in sum, 41 interviewees were included across the five local sites. Additional interviews were conducted with the Deputy Director General of FiA and the national coordinator of CCF. Evaluation team members aimed to triangulate by verifying key information with interviewees representing different sectors and perspectives, then conducted follow-up checks to confirm findings and minimize errors in interpretation. Additional interviews conducted in 2012 and 2013 with other actors, including those not directly involved in the AIC process but knowledgeable about the broader shifts described, served to triangulate observations on outcomes.
The three most significant outcomes of the initiative were each unanticipated, though very much in line with its purpose. Two represent shifts in fishery access rights and resource management authority, while the third is a shift in institutional relationships. This section details each of these main outcomes.

\section{The release of fishing lot number 1}

Fishing lot number 1 in Kompong Thom Province was terminated in October 2010, with the Ministry of Agriculture, Forestry, and Fisheries granting access rights to local fishers. The newly released area, measuring 2684 hectares, represents a significant resource for local livelihoods. Despite similar local complaints and conflicts in other sites around the lake and along the Mekong and Tonle Sap rivers, this was the first fishing lot to be released to community control since the major reforms of 2000/2001, marking it an important outcome at both local and national levels.

Indeed, locals in Phat Sanday had repeatedly made earlier requests for access to better fishing grounds, including efforts to swap seasonally-flooded portions of their existing community fishery zone for the more productive zone within the lot. The community fishery chief had organized petitions and pressed the villagers' case with delegations of senior officials from Phnom Penh visiting the area. What made the difference this time? Local interviewees point to a convergence of factors.

"We don't have many opportunities to raise these issues at the provincial level," said Long Sochet, the national CCF organizer, highlighting one of the turning points in the process. The 
provincial dialogue provided a constructive setting for the local community fishery chief to present the community perspective to provincial officials, and his words carried more weight when a cantonment fishery official who had participated in the local dialogue confirmed the concerns he raised. A fisheries official from the inspectorate level then suggested a follow-up roundtable, which explored the options in more depth and with other officials involved.

"More active communication and engagement from senior officials helped support the lot's release," reported Oum Meng, community fishery chief in Phat Sanday. Emboldened by the encouragement they received at the provincial level, local village leaders decided to organize a new petition, endorsed by local authorities and with the support of CCF. The petition was delivered to the National Assembly, and Nguom Ngel, second deputy president of the National Assembly, responded by organizing a visit to Phat Sanday, accompanied by the Minister of Agriculture and the Director General of FiA. According to participants in the meeting, despite reluctance on the part of the Ministry of Agriculture, Forestry, and Fisheries to consider a release given that over half the surface area of fishing lots on the lake had already been released to communities in the reforms of 2000/2001, Nguom Ngel replied that "there's nothing we can't resolve."

In their efforts to make links to the National Assembly and Senate, FACT and CCF were also supported from 2010 by an NGO in Phnom Penh called the Advocacy and Policy Institute (API). The Institute works on a wide range of policy issues, helping arrange meetings with parliamentary groups, prepare community members for these meetings, prepare briefing notes, and follow up with officers of the National Assembly and Senate afterward. In the case of the release of fishing lot number 1, such meetings "must have influenced the decision," said Lam Socheat of API, because they provided an opportunity for community members to make their case and present evidence. CCF was also vocal in the media at the time, particularly through radio interviews in calling for government action to expand community fisheries and crack down on illegal fishing.

The President of the Senate subsequently backed the idea of a release, it was debated internally at the highest levels of government, and the Ministry of Agriculture, Forestry, and Fisheries decision was later announced by radio, to the joy and astonishment of villagers who had long pressed for a change. For other communities on the Tonle Sap, this experience demonstrated the possibilities for effective advocacy. It also helped strengthen the community's relations with government, and influenced the strategic thinking of $\mathrm{CCF}$ about its role in relation to government.

The FiA, although historically cautious in attributing policy influence to civil society action, also corroborates this chain of influence. Ms. Kaing Khim, a Deputy Director General of FiA, reflecting in November 2013 on the collaboration of three years prior, noted that "The initiative built local awareness and capacity in communication, relationship-building, and collaboration, through provincial dialogues and other activities, so that local people (fishers and community fishery members) felt confident to speak out, to bring their voices and needs forward and communicate with relevant agencies and leaders. It also helped local groups build closer relationships with FiA at all levels and with other authorities to bring local needs and voices to the provincial governor and especially to the Parliamentary Representative of Kampong Thom province [who] could then convey the issue and people's needs to the top level of government, which proved essential in the decision to release fishing lot number 1 in Kompong Thom province." In a January 2013 meeting, the Director General of the FiA also cited civil society engagement as an important contributing factor in the release of fishing lot number 1 as well as subsequent national reforms.

\section{A negotiated agreement to resolve a boundary dispute}

One of the most challenging conflicts over resource access identified in the research process concerned a disputed area claimed by community fishery organizations from Koh Chiveang, near Prek Toal in Battambang province, and Keo Por, in neighboring Siem Reap province. The concerns emerged in both local and provincial dialogues in the two provinces but could not be effectively addressed at these levels because the dispute crossed provincial boundaries.

Following the national dialogue, FiA and CCF team members agreed that the boundary dispute was a top priority for followup intervention, and worked together to organize a negotiation on site. Direct negotiations between the local parties resulted in an agreement to designate the disputed area a jointly managed fishing ground, and established a joint management committee for the purpose.

Interviewees credit the open process of negotiation, which genuinely explored alternative options to resolve the dispute, for building mutual awareness and raising the level of trust among local stakeholders to a point where a jointly implemented solution became feasible. This entailed a very different posture for FiA than it had typically played, where its role was not to impose a settlement through its interpretation of policy but rather to convene a dialogue in which the full range of local stakeholders had an opportunity to present their perspectives on the problem. Although the convening role of FiA was essential, along with the institutional support it provided to reach and enforce an agreement, the terms of the agreement were locally defined. FiA officials had initially proposed designating the disputed area a conservation zone.

"I pointed out that if you accept this solution, there will be no more fishing in the zone, and people won't be allowed to travel through the area either, which is an important travel route," said Long Sochet, the national CCF coordinator. By exploring the implications of various management options on all parties involved, the stakeholders were able to arrive at a solution perceived by all sides as legitimate, which participants said would likely not have occurred in the case of a solution imposed from above.

\section{A shift in strategy for the Coalition of Cambodian Fishers}

The Coalition of Cambodian Fishers acts in a variety of roles: as an advocate for the interests of fishing communities, as a conduit for capacity building, and as a vehicle for information sharing between geographically disparate communities. As a result of CCF's involvement in this initiative and bolstered by the outcomes described above, this grassroots network shifted its strategy in two important ways. 
Table 1. Additional outcomes (case study sites in parentheses).

\begin{tabular}{lll}
\hline \hline Type of Relationship & \multicolumn{2}{c}{ Type of Change } \\
\cline { 2 - 3 } & Improving Representation & Strengthening Accountability \\
\hline $\begin{array}{l}\text { Within and between } \\
\text { villages }\end{array}$ & $\begin{array}{l}\text { Increased cooperation between neighbouring community } \\
\text { fishery organizations (CF) with assistance from CCF (Ta }\end{array}$ & $\begin{array}{l}\text { Neighboring CFs have engaged in joint patrols to combat } \\
\text { illegal fishing and flooded forest harvesting (Ta Mol Leu) }\end{array}$
\end{tabular}

Mol Leu)

Increased reporting of illegal activity, more meetings between Improved relations between neighboring commune councils, the commune council and $\mathrm{CF}$, more patrols by $\mathrm{CF}$ members, as well as between the $\mathrm{CF}$ and local villagers (Kg Khleang) and more effective collection of illegal fishing equipment (Kg Khleang)

Villages \& NGOs or Neighboring CFs in dialogue to resolve dispute with civil society networks assistance from CCF (Prek Toal)

NGOs operating in the area have been more open to input from local villagers (Anlong Raing)

Villages \& local admin.
Improved relations between the police, the community, and the military police (Anlong Raing)

More effective collaboration between fisheries officers, environment officers, and the $\mathrm{CF}$, with more ad hoc meetings organized to deal with emerging issues $(\mathrm{Kg}$ Khleang)
Increased interaction with neighboring commune councils, resulting in better protection of flooded forests ( $\mathrm{Kg}$ Khleang) $\mathrm{CF}$ is increasing engagement with NGOs to raise awareness amongst villagers of laws regarding natural resource management (Phat Sanday)

Villagers' increased knowledge of the working of NGOs in the area has helped obtain support for the construction of a school and a building for the CF, as well as seek support for further projects (Anlong Raing)

More open communication between villagers and fisheries officers, resulting in better control of illegal fishing ( $\mathrm{Ta} \mathrm{Mol}$ Leu)

More community-based organizations formed to improve local livelihoods, and these organizations are working more with fisheries and environment officers through joint training and workshops (Phat Sanday)

Improved relationship between the $\mathrm{CF}$ and the fisheries and environment officers, with better responsiveness to reports of illegal activities and calls for assistance in law enforcement (Phat Sanday)
"We have learned from this experience realizing how important it is to bring people together at the village level, at the commune level, and then to take these issues to discuss at the provincial level. We've seen how this can help those above understand the problems that local people face," explained Long Sochet, the national CCF coordinator. Having observed and practiced stakeholder facilitation using the AIC approach, the core team members from CCF worked to replicate and adapt the process in other locales, especially where communities were constrained by the fishing lots or faced disputes over access to and management of fisheries resources. In a January 2013 meeting, the Director General of $\mathrm{FiA}$ noted that he has maintained regular consultations with CCF, typically on a monthly basis, in the years since the collaboration, and cited this link as an important way to keep in touch with local concerns before they reach the point of tension.

Additionally, CCF implemented internal organizational changes aimed at strengthening and formalizing its links with established NGOs in a range of rural development sectors beyond its longstanding links with FACT, and improving its capacity to collaborate with and influence government. Although CCF was frequently vocal in its criticisms of government and had managed to attract media attention through a protest stance, it had achieved little measurable influence on actual policy implementation in the past. As a result of this collaboration, the network established a permanent board of representatives from national and local NGOs to coordinate action, share information, and advise the $\mathrm{CCF}$ on its strategy. As a grassroots organization lacking the formal status of an NGO, CCF organizers see formalizing these links as a way to extend their capacity for collective action across different regions and from local to national levels.

\section{Additional outcomes}

Beyond these three principle outcomes, a suite of additional positive outcomes were identified, which include more preliminary efforts at managing local disputes and instances of improved collaboration among community fishery organizations and local authorities (Table 1). Taken together with the set described above, these outcomes include shifts in the three dimensions of governance outlined by Ratner et al. (2013a): stakeholder representation, distribution of authority, and mechanisms of accountability. Some of these additional outcomes clearly cited the dialogue events as the primary or contributing factor in the changes, for others the attribution is less clear or direct. Though interviewees were asked to identify both positive and negative changes, no negative outcomes attributed to the dialogue workshops or subsequent efforts at collective action were reported. The only negative changes reported concerned general livelihood issues, such as declining 
fish stocks or difficult rice markets. Table 1 summarizes those additional outcomes that were deemed either clearly attributable to the initiative or likely influenced by it; all are positive changes from the perspective of community fishery members, the main beneficiary group identified at the outset.

Despite significant follow up, over half of the local outcomes that were deemed plausibly influenced by the initiative were excluded because the team was unable to confirm the findings in the time available. In future applications, an outcome evaluation process repeated at staged intervals over a longer period could reveal more about the stakeholder dynamics and processes of adaptation and learning as they unfold. A systematic effort to follow individual interviews with group interviews to sort out differences in opinion or interpretation could also enhance the consistency of findings. The interviews with participants and nonparticipants in the original dialogues provided a useful check on the observations made. Nevertheless, devoting more time to unraveling the complex web of interactions and storylines at each site could likely yield a more complete picture of outcomes and the particular influence of the AIC process in relation to other factors.

\section{LESSONS}

What lessons can we draw from this initiative regarding the application of AIC, and the factors needed to catalyze collective action to improve management of contested natural resources?

\section{Collective action and governance}

Making sound choices for policy and governance reform requires multistakeholder dialogue and authentic deliberation over possible courses of action (Andrew et al. 2007, Armitage et al. 2009). However, the mechanisms for such dialogue are often absent or underdeveloped, particularly with regard to linkages across scales, and among civil society, government, and private sector actors (Ratner and Allison 2012). Precisely because so many problems of natural resource management cannot be solved at the level of the farmer's plot or the fishing household, the ability to foster collective action is especially important (Knox et al. 2002).

This initiative employed AIC as a means of influencing the "action arena" in which natural resource disputes play out (Ratner et al. 2013b), by introducing a structured process of stakeholder engagement that, at least temporarily, shifted the power dynamics typical of interactions among these stakeholders, supporting new partnerships and patterns of interaction. The dialogue workshops revealed, for example, that community fishery members were often very practiced at raising problems that they felt demanded government action but were less experienced at working through the practicalities of different possible responses, considering the perspectives of police, fisheries officers, and commune and district officials. Likewise, FiA officers were typically more comfortable working in the mode of explaining the law or implementing enforcement decisions, while creating a forum to hear different views prior to reaching judgment required much more purposeful effort and preparation. Additionally, some representatives selected by their peers to represent community interests at the provincial level had little prior experience doing so, such as a female village chief who surprised provincial officials with her articulate presentation of conclusions from the local dialogue.

The core team's efforts were focused on setting goals for the initiative as a joint undertaking, framing the domain of the system in question, and ensuring as much as possible integrity of the process, in keeping with the AIC principles outlined above. Importantly, the team did not try to influence the priorities that emerged from the dialogue events, though it did work to reinforce the norms of joint analysis and collaborative decision making in important ways outside of the formal events. In several instances, the shifts in stakeholder relationships have endured now for several years, which indicates an incremental but nevertheless positive contribution toward improving governance. There were of course losers in the changes observed, particularly the operators of lot number 1, who lost access and use rights to fishing grounds released to communities. However, compared with the gains in income, food security, and nutrition that are expected for local fishing families, as well as associated opportunities in processing, trade, and support services in the local economy, these losses appear justifiable from an equity perspective.

\section{Networks and cross-scale linkages}

Community fishery groups around the Tonle Sap confront problems that cannot be solved at the scale of management at which they have operated for many years. This need to bridge scales is a common challenge of social-ecological system governance in developed and developing country environments alike (Olsson et al. 2004, Lebel et al. 2006, Armitage et al. 2009, Gooch and Warburton 2009, Berkes 2010, Cundill and Fabricius 2010). Analysis and practice requires a shift from a static view of state-society relations to networked, multilevel governance interactions (Leach et al. 2007), which enables a clearer focus on processes of empowerment, mobilization, networking especially among civil society groups.

The approach of an initiative jointly owned and managed by a grassroots network and a national line agency, unusual in the Cambodian context, was essential in building trust among these stakeholders working at different scales, helping accrue social capital to create a sense of shared purpose (Armitage et al. 2009) that ultimately contributed to a willingness to collaborate in resolving local disputes. This initiative worked to promote change within an already highly developed mosaic of social relationships, some of which were apparent to the core team at the outset, some of which only became apparent during the action research process. The prior working relationships and trust between members of the research team and FiA was critical in making the case for inclusion of the $\mathrm{CCF}$ as a core partner in the initiative. Existing relationships of key participants in the dialogue workshops were also essential in influencing outcomes. The community fishery leader in Phat Sanday, for example, had worked over many years to help organize petitions requesting a release of fishing lot number 1 . When given the opportunity at the provincial dialogue to speak before officials gathered in a structured setting designed to deliberately build appreciation of divergent perspectives, he was able to gather support in a way that enabled subsequent connections at higher levels. When the Chief of the Fisheries Inspectorate voiced his support for addressing the lot issue in the Kompong Thom provincial dialogue, other agency representatives and local officials followed suit, a dynamic that would likely not have played out in a series of individual meetings, in which officials are typically more cautious when unsure how others will act. National Assembly representatives, subsequently, responded to these advocacy efforts and helped provide access to "policy windows" (Fabricius et al. 2007) so that civil society voices could influence decision making. 
Achieving these sorts of connections that engage actors across administrative levels, and creating an environment for dialogue in which participants take on unfamiliar roles that help identify such opportunities, requires visible, high-level support and effective brokering. Though initially skeptical, the Director General of FiA became convinced of the importance of the initiative and provided a strong authorizing environment that signaled to the core team and FiA staff at all levels that this initiative was a high priority. This support helped ensure participation of senior officials at the provincial level and appropriate officers from a range of agencies at local levels. In parallel, CCF employed its own influence network to ensure appropriate participants engaged in the process from civil society groups and NGOs. Although the core team shared facilitation responsibilities, a senior official such as the Deputy Director General of Fisheries or a representative of the Provincial Governor convened each provincial meeting, and was carefully briefed to help establish an atypical tone, one of joint exploration.

Social networks also proved critical at the community level, providing incentives for individuals to follow up on the commitments they had made publicly at the dialogue events, for example by arranging meetings with officials or seeking intervention to resolve disputes, independent of any project or formal monitoring structure. Typical rural development projects aim to maximize the realm of control with detailed implementation plans, activities, and objectives, an internal project management structure that absorbs significant resources, and regular supervision and monitoring of local activities as incentives to implement according to plan (Ellerman 2006). In the AIC process, because the locus of decision making over strategies for the future and the freedom to choose courses of action lie with the stakeholders involved, the incentives are different. Having engaged in a difficult process together to develop a shared appreciation of the whole context, influenced each other, and made their individual or collective commitments public, participants described their motivation to follow through based not on external monitoring but on the social reinforcement that comes from other actors who expect accountability for those commitments.

\section{Fostering the conditions for transformation}

Folke et al. (2010) recognize that transformation of socialecological systems at large scales is linked to processes of transformation occurring at smaller, nested, scales. Similarly, the AIC model draws a connection between change at the level of the whole system, as defined for a particular initiative, the network of stakeholder relationships over which one has influence, and the more immediate domain of an individual's or group's control (the organization vector in Fig. 1). In facilitating the local, provincial, and national stakeholder dialogue events, the core team drew on a range of participatory tools and techniques to encourage reflection across these three dimensions: what the actors need to appreciate, what they can influence, and what they can choose to change. These included small group exercises to visualize and communicate alternative futures and describe present realities, network mapping to represent the relationships among stakeholders and their relative influence, as well as visual depictions of the factors and actors that could advance or deter progress toward shared goals. (For further details on the process, see Ratner and Smith 2014.)
No matter the technique or the facilitator, however, the most important interventions concerned efforts to reaffirm the purpose and the principles at play, and sometimes these occurred outside the formal dialogue process. For example, core team members worked to protect the autonomy of each participant to make decisions, which yields a more authentic commitment to collective action than would be achieved through a coerced gathering of volunteers. These repeated efforts to reaffirm the core purpose and principles aimed to uphold the six conditions for transformation defined by Smith (2008), as summarized in Box 1.

\section{Text Box 1. Six conditions for transformation}

1. Focus on a real pressing need. People engaged because fisheries are central to their livelihoods and they perceive these livelihoods at risk.

2. Organize around a purpose that transcends the interests of every stakeholder. The organizing process focused on securing a livable future, expressed variously in terms of strengthening social-ecological resilience, reducing conflict, and sustaining livelihoods.

3. Ensure the whole system is represented in the process. Dialogues included the widest possible range of private, public, and civil society actors at each level, and those who were not initially included were often engaged through follow-up actions after participants determined they had an influential role in the problem or solution at hand.

4. Provide equal opportunity for all to participate. Although typical meetings are dominated by the most senior officials (usually men), the dialogue processes improved the balance of voices through a purposive selection of participants representing different groups (including attention to gender balance) and a structure that required each to be heard.

5. Respect the autonomy of each participant. Participants worked hard, at the appropriate phase in the process, to influence each other's perspectives, but facilitators made clear that commitments for action, in particular, are voluntary.

6. Structure the process to provide a way for participants to make use of all three powers. Although participants often arrive with the expectation that formal authority (control) is the only power that matters, the process provided numerous demonstrations of how the powers of influence and appreciation enable new possibilities for collective action.

Source: Smith (2008), with Tonle Sap examples added by the authors

Although the principles are by nature an ideal, in practice such a process is often fraught with obstacles. Indeed, this initiative met with a series of crises that could have derailed the collaboration altogether. The first crisis came at the outset, when the FiA Director General, frustrated with past public statements by the $\mathrm{CCF}$, declared he would not support the proposal to partner. The second arose from an internal dispute within the project team 
concerning budget allocation and decision-making authority. The last, and most serious, followed a radio interview by the CCF national coordinator that angered the Director General to the point that he was prepared to call off the national dialogue event. In each instance, the effort to resolve the crisis proved a major step forward in achieving the overall purpose, because it served to clarify the commitment to joint ownership of the initiative. Rather than glossing over differences, these were made explicit; the team worked to understand the root of each concern and the complementary values this pointed toward, recognized the challenge and agreed to work to bridge it.

\section{DISCUSSION}

The AIC process examined here provides a route to address several persistent challenges of putting resilience thinking into practice amidst power inequities and long-term conflict over natural resources. Creating a structured process of dialogue helped bridge gaps in communication and awareness to increase the effectiveness of collective action, contributing to tangible shifts in resource access and management of specific disputes. Working with existing social networks, this process also helped stakeholders identify alternative routes to improve cross-scale interactions, and some of these, such as the regular consultations between CCF and FiA, have now endured over several years. Finally, explicitly addressing differences in power and sources of tension among partners helped reinforce the underlying principles of collaborative problem solving, which proved essential in making the dialogue events work as well as sustaining new patterns of interaction over the long term.

These lessons reinforce the observations by Adger et al. (2005) that although cross-scale interactions can reinforce power inequities, they may also have positive effects, building awareness and promoting learning about the underlying causes of resource conflict, and helping identify responses. When managed effectively through dialogue rather than turning destructive, conflict can provide a focal point that encourages communication and relationship-building among diverse stakeholder groups (Folke et al. 2005).

From a resilience perspective, the capacity to manage conflict within a social-ecological system is an essential determinate of the prospects for system-level transformation. Arguably, the Tonle Sap Lake fishery, a social-ecological system that affects the health and food security of millions, is in the midst of such a transformation. This extends back at least to the mid-1990s, a period when rising pressures on the fishery produced overt conflicts preceding the first wave of policy reforms in 2000/2001, and has continued through the recent wave of reforms in 2011/2012 that saw the complete removal of commercial fishing lots (Ratner 2011, Cambodia New Vision 2012). However, the risks to fisheries livelihoods remain high, as the economic viability of small-scale fishing is under pressure by increased competition and declining catch per unit effort (Hap and Bhattarai 2009), illegal fishing remains widespread, and water resource infrastructure and land-use changes threaten to further undermine fisheries productivity within the lake basin and at the larger scale of the Mekong River basin (Dugan et al. 2010, Ziv et al. 2012).
This broader story is still unfolding, and the long-term outcomes in terms of ecosystem functions, productivity, livelihoods, incomes, and nutrition are not yet clear. Likewise, progress in institutional transformation, toward a system in which the poor and vulnerable are ensured a voice in decision making, and in which authorities are held accountable for the outcomes of their actions in terms of equity and ecosystem sustainability, remains very incomplete. The initiative described here represents but one small effort amidst a complex set of institutions and stakeholder interactions, yet it provides evidence that purposeful efforts to transform stakeholder relationships can indeed yield positive improvements within this very challenging context.

\section{CONCLUSION}

The experience documented here demonstrates the potential of AIC as an open-ended process of stakeholder engagement and action research that can enable collective action and contribute to improvements in natural resource governance, even amidst ongoing resource conflict. It also suggests a strong case for continued efforts to adapt the AIC approach and to learn from its application in a range of other contexts. As a single case study, this does not establish the broad applicability of the approach, but it does serve as a proof of concept (Flyvbjerg 2006). A followon initiative has further developed the application of AIC in the Tonle Sap, including efforts to address the challenges of enforcement and explore the potential for community-based commercial production in the postreform period. It has also adapted the approach in Lake Kariba in Zambia and Lake Victoria in Uganda (Ratner et al. 2014), demonstrating its viability in other socio-political environments.

As the approach is applied in other domains, it will be essential to document and compare the lessons that emerge to improve the practice of supporting resilience, adaptation, and transformation in large social-ecological systems. Undertaking such comparisons, then accumulating the lessons of practice from multiple experiences, will also require a broad range of approaches to evaluating process and outcomes. These include methods that capture unanticipated change from participant perspectives, as exemplified by this case, alongside more structured measures of shifts in social networks, information-sharing, conflict, and collaborative decision making.

Responses to this article can be read online at: http://www.ecologyandsociety.org/issues/responses. $\mathrm{php} / 6400$

\section{Acknowledgments:}

The experience related in this paper represents a collective undertaking. The action research team included: Kaing Khim, Ly Vuthy, Ouk Vibol, and Keo Sovatapheap (Fisheries Administration); So Sovannarith, and Kim Sour (Cambodia Development Resource Institute); and Om Chhim, Chheng Kim Heng, Ke Sothy, Keo Rotha, Hout Han, and Long Sochet (Coalition of Cambodian Fishers), in addition to authors Blake Ratner and Mam Kosal (WorldFish). The outcome evaluation team 
was comprised of Mam Kosal, Guy Halpern, Eam Dyna, and Chea Seila, with guidance from Mark Dubois on the Most Significant Change methodology. For guidance and support on behalf of the Fisheries Administration, the team is indebted to H. E. Nao Thuok, Fisheries Administration Director General. For guidance and feedback on the AIC approach, our thanks go to William E. Smith. Carol Colfer, Eric Haglund, Jane Pratt, Kaing Khim, and Lieng Sopha each provided helpful review comments on an earlier version of this paper, which appeared in the CGIAR Systemwide Program on Collective Action and Property Rights (CAPRi) Working Paper Series. Thanks also to three anonymous reviewers for critical comments and suggestions. The initiative was financed primarily by CAPRi as part of a broader set of grants on the theme of securing rural people's access to natural resources. Subsequent work on this article was supported by the CGIAR Research Program on Aquatic Agricultural Systems, and the CGIAR Research Program on Policies, Institutions, and Markets to Strengthen Food Security and Incomes for the Rural Poor.

\section{LITERATURE CITED}

Adger, W. N., K. Brown, and E. L. Tompkins. 2005. The political economy of cross-scale networks in resource co-management. Ecology and Society 10(2): 9. [online] URL: http://www. ecologyandsociety.org/vol10/iss2/art9/

Andrew, N. L., C. Béné, S. J. Hall, E. H. Allison, S. Heck, and B. D. Ratner. 2007. Diagnosis and management of small-scale fisheries in developing countries. Fish and Fisheries 8:227-240. http://dx.doi.org/10.1111/j.1467-2679.2007.00252.x

Armitage, D. R., R. Plummer, F. Berkes, R. Arthur, A. Charles, I. Davidson-Hunt, A. Diduck, N. C. Doubleday, D. S Johnson, M. Marschke, P. McConney, E. W. Pinkerton, and E. K. Wollenberg. 2009. Adaptive co-management for social-ecological complexity. Frontiers in Ecology and the Environment 7(2):95-102. http://dx.doi.org/10.1890/070089

Bandyopadhyay, K. K., and T. C. Khus. 2013. Changing civil society in Cambodia: in search of relevance. Development in Practice 23(5-6):665-677. http://dx.doi.org/10.1080/09614524.2013.800835

Berkes, F. 2010. Devolution of environment and resource governance: trends and future. Environmental Conservation 37 (4):489-500. http://dx.doi.org/10.1017/S037689291000072X

Cambodia New Vision. 2012. Elaborations on contract fishing and overall fishery reforms. Issue 169, 8 March. Government of Cambodia, Phnom Penh, Cambodia. [online] URL: http://cnv. org. kh/cnv html pdf/cnv 169 mar 12.pdf

Chambers, R., A. Cornwall, J. Gaventa, S. Musoki, J. and Pettit. 2006. Participatory learning and action: critical reflections, future directions. Institute of Development Studies, Sussex, UK.

Cundill, G., and C. Fabricius. 2010. Monitoring the governance dimension of natural resource co-management. Ecology and Society 15(1): 15. [online] URL: http://www.ecologyandsociety. org/vol15/iss1/art15/

Dart, J. J., and R. J. Davies. 2003. A dialogical story-based evaluation tool: the most significant change technique. American Journal of Evaluation 24:137-155.
Dugan, P. J., C. Barlow, A. A. Agostinho, E. Baran, G. F. Cada, D. Chen, I. A. Cowyx, J. W. Ferguson, T. Jutagate, M. MallenCooper, G. Marmulla, J. Nestler, M. Petrere, R. L. Welcomme, and K. O. Winemiller. 2010. Fish Migration, Dams, and Loss of Ecosystem Services in the Mekong Basin. Ambio 39:344-348. http://dx.doi.org/10.1007/s13280-010-0036-1

Ellerman, D. 2006. Helping people help themselves: From the World Bank to an alternative philosophy of development assistance. University of Michigan Press, Ann Arbor, Michigan, USA.

Fabricius, C., C. Folke, G. Cundill, and L. Schultz. 2007. Powerless spectators, coping actors, and adaptive co-managers: a synthesis of the role of communities in ecosystem management. Ecology and Society 12(1): 29. [online] URL: http://www.ecologyandsociety. org/vol12/iss1/art29/

Flyvbjerg, B. 2006. Five misunderstandings about case-study research. Qualitative Inquiry 12(2):219-245. http://dx.doi. org/10.1177/1077800405284363

Folke, C., S. R. Carpenter, B. Walker, M. Scheffer, T. Chapin, and J. Rockström. 2010. Resilience thinking: integrating resilience, adaptability and transformability. Ecology and Society 15(4): 20. [online] URL: http://www.ecologyandsociety.org/vol15/iss4/ art20/

Folke, C., T. Hahn, P. Olsson, and J. Norberg. 2005. Adaptive governance of social-ecological systems. Annual Review of Environment and Resources 30:441-473. http://dx.doi.org/10.1146/ annurev.energy.30.050504.144511

Furugganan, B., and M. A. Lopez. 2002. Building partnerships between government and civil society: the case of Paiboon Wattanasiritham and the Governmental Central Bank. Asian Institute of Management, Bangkok, Thailand. [online] URL: http://www.synergos.org/bridgingleadership/04/c_5_case_study_khun paiboon wattansiritham thailand.pdf

Gaventa, J. 2006. Finding the spaces for change: a power analysis. IDS Bulletin 37(6):23-33. http://dx.doi.org/10.1111/j.1759-5436.2006. $\underline{\text { tb00320.x }}$

Gooch, M., and J. Warburton. 2009. Building and managing resilience in community-based NRM groups: an Australian case study. Society \& Natural Resources 22:158-171. http://dx.doi. org/10.1080/08941920801967880

Gunderson, L., C. Folke, M. A. Janssen. 2007. Reflective practice. Ecology and Society 12(2): 40. [online] URL: http://www. ecologyandsociety.org/vol12/iss2/art40/

Hap, N., and M. Bhattarai. 2009. Economics and livelihoods of small-scale inland fisheries in the Lower Mekong Basin: a survey of three communities in Cambodia. Water Policy 11:31-51. http:// dx.doi.org/10.2166/wp.2009.002

Jacobs, K., L. Lebel, J. Buizer, L. Addams, P. Matson, E. McCullough, P. Garden, G. Saliba, and T. Finan. 2010. Linking knowledge with action in the pursuit of sustainable waterresources management. Proceedings of the National Academy of Science http://dx.doi.org/10.1073/pnas.0813125107

Keskinen, M., M. Käkönen, T. Prom, and O. Varis. 2007. The Tonle Sap Lake, Cambodia: water-related conflicts with 
abundance of water. Economics of Peace and Security Journal 2 (2):49-59.

Keskinen, M., and O. Varis. 2012. Institutional cooperation at a basin level: for what, by whom? Lessons learned from Cambodia's Tonle Sap Lake. Natural Resources Forum 36:50-60. http://dx.doi. org/10.1111/j.1477-8947.2012.01445.x

Knox, A., R. Meinzen-Dick, and P. Hazell. 2002. Property rights, collective action, and technologies for natural resource management: a conceptual framework. Pages 12-44 in R. Meinzen-Dick, A. Knox, F. Place, and B. Swallow, editors. Innovation in natural resource management: the role of property rights and collective action in developing countries. Johns Hopkins University Press and International Food Policy Research Institute, Baltimore, Maryland, USA.

Layanun, P. 2004. Health promotion for Thai garment factory workers. The World Health Organization, Geneva Switzerland. [online] URL: http://www.odii.com/papers/Health Promotion Thai Garment.pdf

Leach, M., G. Bloom, A. Ely, P. Nightingale, I. Scoones, E. Shah, and A. Smith. 2007. Understanding governance: pathways to sustainability. STEPS Working Paper 2. STEPS Centre, Brighton, UK. http://steps-centre.org/wp-content/uploads/final_steps_governance. pdf

Leach, M., I. Scoones, and A. Stirling. 2010. Dynamic sustainabilities: technology, environment, social justice. Earthscan, Abingdon, UK.

Lebel, L., J. M. Anderies, B. Campbell, C. Folke, S. HatfieldDodds, T. P. Hughes, and J. Wilson. 2006. Governance and the capacity to manage resilience in regional social-ecological systems. Ecology and Society 11(1): 19. [online] URL: http://www. ecologyandsociety.org/vol11/iss1/art19/

MacNeil, J. D. 1998. The AIC process: generating shared visions for community development in Southeast Asia. Center for International Education, University of Massachusetts, Amherst, Massachusetts, USA. [online] URL: http://www.odii.com/ papers/Generating Shared visions thai McNeale.pdf

Mayne, J., and E. Stern. 2013. Impact evaluation of natural resource management research programs: a broader view. ACIAR Impact Assessment Series Report No. 84. Australian Centre for International Agricultural Research, Canberra, Australia. [online] URL: http://aciar.gov.au/files/ias84.pdf

McIntyre, A. 2008. Participatory action research. Sage, London, UK.

Narayanasamy, N. 2009. Participatory rural appraisal. Sage, New Delhi, India.

Olsson, P., C. Folke, and T. Hahn. 2004. Social-ecological transformation for ecosystem management: the development of adaptive co-management of a wetland landscape in southern Sweden. Ecology and Society 9(4): 2. [online] URL: http://www. ecologyandsociety.org/vol9/iss4/art2

Patton, M. Q. 1990. Qualitative evaluation and research methods. Sage, Newbury Park, California, USA.
Participatory Research in Asia (PRIA). 2012. Civil society@ crossroads: shifts, challenges, options? PRIA, New Delhi, India. [online] URL: http://www.intrac.org/data/files/resources/757/ Civil-society-at-a-Crossroads-Global-Synthesis-Report.pdf

Ratner, B. D. 2011. Common-pool resources, livelihoods, and resilience: critical challenges for governance in Cambodia. IFPRI Discussion Paper Series. International Food Policy Research Institute, Washington, D.C., USA.

Ratner, B. D. 2013. Building resilience in rural livelihood systems as an investment in conflict prevention. Chapter 21 in $\mathrm{H}$. Young and L. Goldman, editors. Livelihoods, natural resources, and postconflict peacebuilding. Earthscan, London, UK.

Ratner, B. D., and E. H. Allison. 2012. Wealth, rights, and resilience: an agenda for governance reform in small-scale fisheries. Development Policy Review (30)4:371-398. http://dx. doi. org/10.1111/j.1467-7679.2012.00581.x

Ratner, B. D., C. Burnley, S. Mugisha, E. Madzudzo, I. Oeur, K. Mam, L. Rüttinger, L. Chilufya, and P. Adriázola. 2014. Dialogue to address the roots of resource competition: lessons for policy and practice. Collaborating for Resilience, Penang, Malaysia.

Ratner, B. D., P. Cohen, B. Barman, K. Mam, J. Nagoli, and E. H. Allison. 2013a. Governance of aquatic agricultural systems: analyzing representation, power, and accountability. Ecology and Society 18(4): 59. http://dx.doi.org/10.5751/ES-06043-180459

Ratner, B. D., R. Meinzen-Dick, E. Haglund, and C. May. $2013 b$. Resource conflict, collective action, and resilience: an analytical framework. International Journal of the Commons 7(1).

Ratner, B. D., and W. E. Smith. 2014. Collaborating for resilience: a practitioner's guide. Guidance Note. Collaborating for Resilience, Penang, Malaysia.

Rüttinger, L., A. Janßen, C. Knupp, and L. Griestop. 2014. From conflict to collaboration in aquatic resource management: a handbook and toolkit for practitioners. Guidance Note. Collaborating for Resilience, Penang, Malaysia, in press.

Salas, M. A., J. T. Herman, N. McKee, and N. Shahzadi. 2006. Visualisation in participatory programmes (VIPP): how to facilitate and visualize participatory group processes. Southbound, Penang, Malaysia.

Schiffer, E., and J. Hauck. 2010. Net-Map: collecting social network data and facilitating network learning through participatory influence network mapping. Field Methods 22 (3):231-249. http://dx.doi.org/10.1177/1525822X10374798

Smith, W. E. 2008. The creative power: transforming ourselves, our organizations and our world. Routledge, New York, New York, USA. http://dx.doi.org/10.4324/9780203888780

Smith, W. E., B. Thoolen, and F. Thoolen. 1980. The design of organizations for rural development. World Bank Staff Working Paper no. 375. World Bank, Washington, D.C., USA.

So, S., B. D. Ratner, K. Mam, and S. Kim. 2014. Conflict and collective action in Tonle Sap fisheries: Adapting institutions to support community livelihoods. CDRI Working Paper Series. Cambodia Development Resource Institute, Phnom Penh, Cambodia, in press. 
Walker, B. H., N. Abel, J. M. Anderies, and P. Ryan. 2009. Resilience, adaptability, and transformability in the GoulburnBroken Catchment, Australia. Ecology and Society 14(1): 12. [online] URL: http://www.ecologyandsociety.org/vol14/iss1/ $\underline{\operatorname{art12l}}$

Walker, B., and D. Salt. 2012. Resilience practice: building capacity to absorb disturbance and maintain function. Island Press, Washington, D.C., USA. http://dx.doi.org/10.5822/978-1-61091-231-0

Weber, M. 1947. The theory of social and economic organization. Free Press, New York, New Tork, USA.

Whyte, W. F. 1984. Learning from the field: a guide from experience. Sage, Beverly Hills, California, USA.

World Bank. 1996. The World Bank participation source book. World Bank, Washington, D.C., USA.

Ziv, G., E. Baran, So Nam, I. Rogríguez-Iturbe, and S. A. Levin. 2012. Trading-off fish biodiversity, food security, and hydropower in the Mekong River Basin. Proceedings of the National Academy of Sciences 109(15):5609-5614. http://dx.doi.org/10.1073/ pnas. 1201423109 